\title{
SERVICE QUALITY IN CASE : KEGAGALAN LAYANAN (SERVICE FAILURE) PERBANKAN SYARIAH DAN STRATEGI PEMULIHAN LAYANAN ( SERVICE RECOVERY)
}

\author{
Djaka Suryadi \\ Dosen STAI Asy-Syukriyyah Tangerang \\ djaka.suryadi@asy-syukriyyah.ac.id
}

\begin{abstract}
Abstrak
Industri jasa perbankan syariah yang merupakan industri jasa yang masih tetap primadona yang menjadi tulang punggung pembangunan, sehingga pemerintah terus memberikan pembinaan yang intens sehingga saat ini peranan pengawasan perbankan Mikro ditangani oleh Otoritas Jasa Keuangan (OJK), sedangkan sector Makro ditangani oleh Bank Indonesia. Penelitian ini menganalisis dampak jenis kegagalan pelayanan (Service Failure) dengan strategi pemulihan layanan (Service Recovery), melalui pendekatan analisis kualitatif studi kepustakaan. Hasil analisis penelitian menunjukkan bahwa Gap Service yang terjadi disebabkan karena kepuasan nasabah itu selalu meningkat hal ini dipengaruhi oleh teknologi dan pesaing yang terus secara kreatif meningkatkan layananannya kepada nasabah dalam rangka mempertahankan keberadaan nasabah loyalisnya
\end{abstract}

Kata kunci : kegagalan, layanan perbankan, strategi pemulihan pelayanan

\section{Abstract}

The sharia banking service industry, which is a service industry that is still excellent, is the backbone of development, so the government continues to provide intense guidance so that currently the role of micro banking supervision is handled by the Financial Services Authority (OJK), while the Macro sector is handled by Central Bank (Bank Indonesia). This study analyzes the impact of types of service failures (Service Failure) with service recovery strategies (Service Recovery), through a qualitative analysis approach to library research. The results of the research analysis show that the Gap Service that occurs due to customer satisfaction is always increasing, this is influenced by technology and competitors who continue to creatively improve their services to customers in order to maintain the presence of loyalist customers

Keywords: banking, service failure, service recovery strategy

\section{A. PENDAhULUAN}

Industri Jasa Perbankan Syariah di Indonesia saat ini terus menunjukkan geliat pertumbuhannya yang terus positif walaupun menujukkan grafik pertumbuhan yang terus 


\section{Jurnal Asy-Syukriyyah}

konservatif jika dibandingkan dengan tahun - tahun sebelumnya namun tetap menunjukkan pertumbuhan yang positif, namun jika dibandingkan dengan perbankan konvensional masih lebih baik pertumbuhannya, menurut data pelaporan Otorotas Jasa Keuangan (OJK) ${ }^{1}$ per Juli 2019 bahwa, perbankan syariah asset per Juli 2019 portfolio 494 Trilyun (11,51\%) dibandingkan dengan konvensional per Juli 2019 portfolio 7,920 Trilyun (8.58\%), menunjukkan bahwa aktivitas perbankan syariah masih terus diminati nasabahnya.

Aktivitas perbankan syariah yang merupakan aktivitas jasa, yang pada kegiatan perbankan yang dilakukan merupakan aktivitas yang mengandalkan kegiatan jasa, dimana peran layanan merupakan aktivitas yang paling utama, sehingga seluruh lini karyawan wajib memberikan layanan prima (service Excellence) hal ini sangat disadari perbankan syariah yang masih harus terus berbenah agar perbankan syariah selalu menjadi pilihan masyarakan Indonesia yang mayoritas Islam. Layanan dengan berbagai bentuk kreativitas baik produk, teknologi dan keramahan layanan yang diberikan merupakan cara perbankan syariah dalam mempertahankan nasabah loyalisnya.

Kegagalan dalam memberikan layanan prima (Service failure) dapat terjadi pada semua tahap, dari awal sampai akhir proses pelayanan. Kesalahan tersebut dapat berupa tidak tersedianya layanan, layanan yang terlalu lambat dan kesalahan-kesalahan lainnya. Seorang nasabah yang datang ke bank mungkin akan langsung merasakan ketidakpuasan saat mulai terlibat dalam proses layanan, seperti pada saat harus menunggu lama untuk dilayani. Ketidakpuasan karena service failure juga dapat terjadi pada saat berhadapan dengan karyawan bank atau bahkan setelahnya.

Kegagalan dalam memberikan layanan prima (Service Failure) pasti pernah dialami oleh semua jasa layanan perbankan, hal ini disebabkan oleh banyak factor : phsikologis, budaya, character, strata sosio ekonomi, dan lain sebagainya. Tentu hal ini harus segera ditangani secara cepat, tepat dan benar agar permasalahan segera dapat diatasi

\footnotetext{
${ }^{1}$ Otoritas Jasa Keuangan (OJK), laporan rutin bulanan perbankan
} 
dan tidak melebar kemana - mana. Diharapkan nasabah menjadi normal kembali dan tentu harus diupayakan untuk tidak terulang lagi pada nasabah tersebut pada masa yang akan datang bahkan perbankan berusaha mengupayakan kearah pada kepuasan. Namun kepuasan juga akan terus berkembang sejalan berkembangnya teknologi, hal ini yang terus harus disikapi oleh perbankan agar nasabah tetap loyal terhadap bank tersebut.

Menurut Lewis dan Spyrakopoulos ${ }^{2}$ service failure merupakan bagian dari service encounter yang menyebabkan permasalahan dan merupakan sesuatu yang perlu diperbaiki oleh organisasi penyedia jasa. Permasalahan tersebut berupa ketidakpuasan nasabah dalam interaksinya dengan layanan atau penyedia layanan. Semua organisasi jasa berada pada situasi yang memungkinkan terjadinya kesalahan atau kegagalan dalam penyampaian produk jasa kepada nasabah sehingga organisasi jasa harus menghadapi ketidakpuasan nasabah. Organisasi jasa harus fokus pada usaha-usaha untuk memperbaiki secara terusmenerus penyampaian jasa (service delivery) karena dalam proses penyampaian jasa seringkali terjadi kesalahan-kesalahan (service failure) yang tidak seluruhnya bisa dihilangkan. Kesalahan-kesalahan tersebut akan menyebabkan nasabah memberikan penilaian yang rendah terhadap kualitas layanan yang disampaikan oleh organisasi, kemudian mereka akan mencari alternatif penyedia jasa lainnya.

Berdasarkan uraian di atas penulis mencoba menganalisis dengan pendekatan kualitatif berdasarkan pendapat para ahli bagaimana kegagalan pelayanan (service Failure) bisa terjadi, cara memulihkannya, dan bagaimana strategi penanganan recovery yang dilakukan.

\section{B. PEMBAHASAN}

\section{Faktor-Faktor yang Mempengaruhi Ekpektasi Nasabah Terhadap Jasa}

Peranan yang sangat penting di dalam evaluasi nasabah terhadap jasa yang mereka konsumsi, pemasar(marketer) butuh(need) dan ingin(want) untuk memahami

\footnotetext{
${ }^{2}$ Lewis, B.R., \& Spyrakopoulos, S. 2001, Service Failures and Recovery in Retail Banking: the Customers' Perspective, Vol.19, No.1, hlm. 37-47
} 
factor - factor apa saja yang membentuknya. Marketer juga ingin memiliki control terhadap semua factor - factor ini, tetapi pada kenyataanya, banyak aspek yang mempengaruhi ekspektasi konsumen terhadap suatu jasa yang ia konsumsi, tidak dapat dikendalikan oleh pihak Marketer.

Menurut Valaria A. Zeithaml, Mary Jo Bitner and Dwayne D. Gremler ${ }^{3}$, telah menyusun sebuah model yang dapat menjelaskan factor - factor yang mempengaruhi ekspektasi nasabah terhadap jasa yang mereka konsumsi.

a. Sumber dari desired Service Expectations

Seperti telah tersusun dalam gambar, dua pengaruh terbesar untuk tingkat jasa yang diinginkan (desired Service Level) adalah pendorong - pendorong jasa yang tahan lama (Lasting Service intensifiers) dan kebutuhan - kebutuhan pribadi (personal Needs). Lasting service intensifiers didefinisikan sebagai factor stabil individual yang mendorong nasabah kepada tingkat sensitifitas yang lebih tinggi terhadap jasa. Satu diantara factor yang terpenting dapat juga disebut ekspektasi ekspektasi jasa turunan (derived service expectations), yang muncul saat ekspektasi konsumen didorong oleh orang lain atau sekelompok orang. Sedangkan factor yang kedua adalah personal service philosophy yaitu sikap dasar umum nasabah tentang makna dari sebuah jasa dan cara yang seharusnya dilakukan oleh para penyedia jasa. Personal needs adalah keadaan atau kondisi yang mendasar untuk nasabah secara fisik maupun psikologis, yang memerankan peran krusial untuk membentuk keinginan konsumen terhadap suatu jasa. Kebutuhan ini bisa bersifat fisik, social, psikologis, maupun fungsional

b. Sumber dari adequate Service Expectations

Terdapat determinan - determinan yang berbeda untuk mempengaruhi ekspektasi - ekspektasi jasa yang cukup (adequate service expectation). Secara umum, pengaruh - pengaruh ini bersifat jangka pendek dan cenderung lebih

${ }^{3}$ Valaria A. Zeithaml, Mary Jo Bitner and Dwayne D. Gremler, Service Marketing - Integrating Customer Focus Across the Firm, 2006, hlm. 934 edition, Mc Graw Hill, New York 
berfluktuasi daripada factor - factor yang mempengaruhi tingkat jasa yang diinginkan (desired service level), terdapat 5(lima) factor :

1) Pendorong - pendorong jasa sementara (temporary service intensifiers) adalah factor individual jangka pendek yang membuat seorang nasabah lebih sadar tentang kebutuhan akan suatu jasa.

2) Alternative - alternative jasa (perceived service alternative) adalah penyedia penyedia jasa lain yang mana nasabah dapat memperoleh jasa yang sama. Jika nasabah memiliki pilihan penyedia jasa yang sama lebih dari satu, atau jika mereka dapat menyediakan jasa bagi mereka sendiri, maka tingkat jasa yang dinilai cukup (adequate service) akan lebih tinggi dari nasabah yang percaya bahwa tidak mungkin untuk mendapatkan saja yang lebih baik di tempat lain.

3) Peran pribadi dalam jasa (self-perceived factors); adalah persepsi nasabah tentang derajat sejauh mana seorang nasabah memiliki pengaruh terhadap tingkat jasa yang mereka terima. Dengan kata lain, ekspektasi nasabah secara parsial terbentuk oleh bagaimana mereka percaya mereka memainkan perannya di dalam proses pengantaran suatu jasa.

c. Sumber Dari Desired and Predicted Service Expectation :

Janji - janji jasa secara eksplisit (explicit service promise) adalah pernyataan - pernyataan personal dan non personal tentang jasa yang dibuat oleh organisasi atau perusahaan kepada nasabah - nasabahnya. Pernyataan ini bersifat personal apabila mereka dikomunikasikan oleh tenaga penjual atau tenaga services atau tenaga pelaksana tugas perbaikan dan mereka menjadi non personal apabila mereka datang dari iklan, brosur dan publikasi tertulis lainnya.

Janji - janji secara implisit (implicit service promise) adalah tanda - tanda yang terkait dengan jasa - jasa selain janji - janji eksplisit yang mengarahkan menuju dugaan mengenai bagaimana seharusnya suatu jasa terjadi maupun akan seperti apa jasa itu terjadi umumnya, harga mendominasi faktor ini, dimana 


\section{Jurnal Asy-Syukriyyah}

semakin tinggi harga, semakin mengesankan bukti - bukti nyatanya, semakin nasabah memiliki ekspektasi tinggi terhadap jasa tersebut.

Komunikasi mulut ke mulut (word - of - mouth communication) adalah pernyataan personal dan kadangkala tidak personal yang dibuat oleh pihak - pihak selain organisasi atau perusahaan kepada nasabah tentang bagaimana pelayanan jasa itu kemungkinan akan terjadi dan mempengaruhi jasa yang diprediksi dan diinginkan terjadi. Pengalaman masa lalu (Past Experience) adalah ekposur masa lalu nasabah terhadap jasa yang bersangkutan.

\section{Gambar 1}

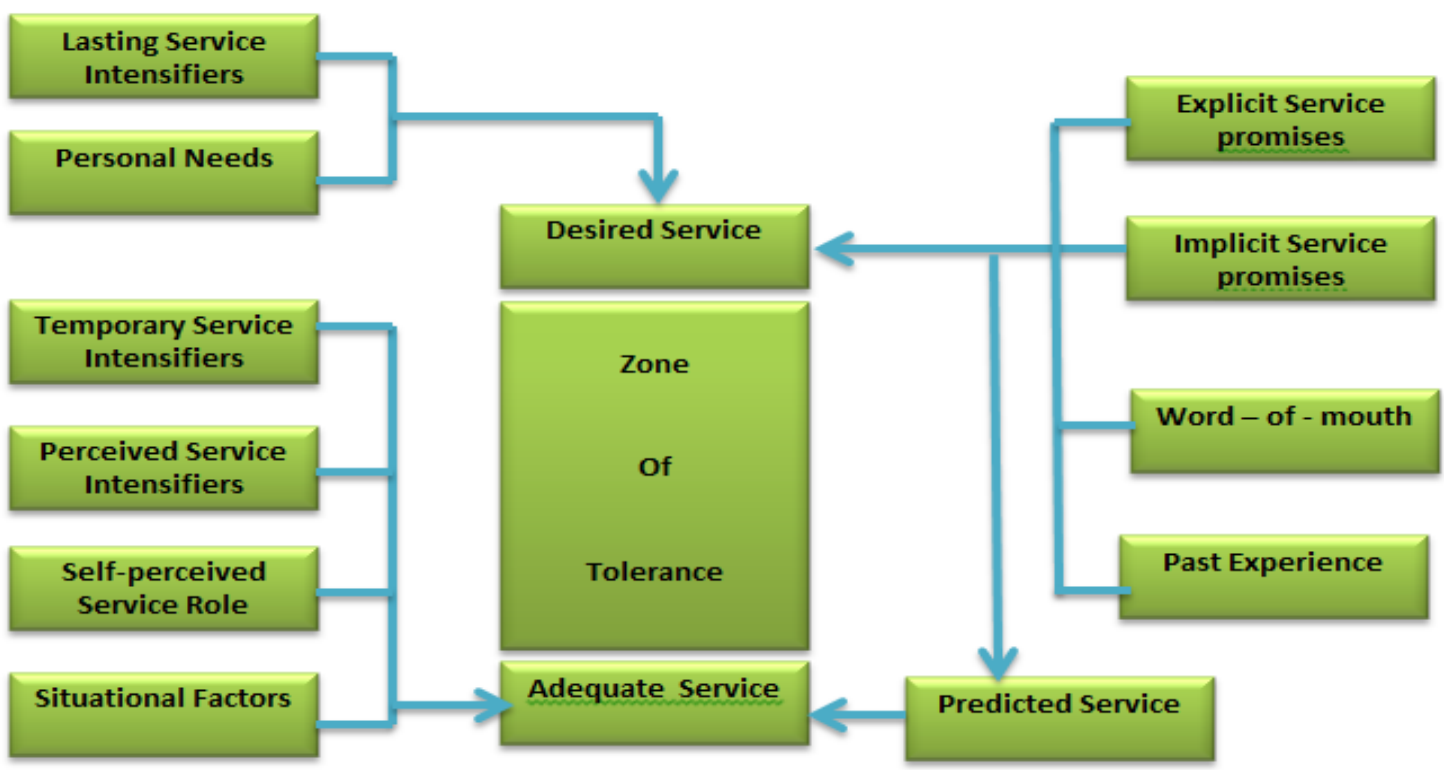

Sumber : Valaria A. Zeithaml, Mary Jo Bitner and Dwayne D. Gremler, Service Marketing - Integrating Customer Focus Across the Firm, 2006, p 934 edition, Mc Graw Hill, New York

\section{Zone of Tolerance}

Setelah memahami satu per satu factor - factor yang mempengaruhi ekspektasi nasabah terhadap jasa, maka diperlukan suatu pemahaman mengenai zona toleransi (Zone of Tolerance) yang berada di antara desired service da adequate service. Secara konseptual. Desired Service adalah tingkat pelayanan yang diharapkan nasabah 


\section{Jurnal Asy-Syukriyyah}

untuk diterima. Sementara itu, seringkali terjadi suatu keadaan, nasabah berharap untuk mencapai keinginan - keinginan mereka terhadap suatu jasa akan tetapi menyadari bahwa ini tidak mungkin akan selalu terjadi. Maka, Adequate Service adalah tingkat jasa yang nasabah masih akan terima.

Zona yang mnggambarkan sejauh mana nasabah menyadari dan berkeinginan untuk menerima variasi di dalam performa jasa yang mereka terima sebagai akibat bervariasinya jasa antar penyedia jasa yang ada, antar karyawan - karyawan dari penyedia jasa yang sama, atau bahkan dengan karyawan yang sama disebut juag zona toleransi (Zone of Tolrenance).

Secara umum, bila jasa berada di bawah Adequate Service - tingkat minimum yang dianggap masih bisa diterima - nasabah akan frustasi dan kepuasan mereka terhadap perusahaan yang bersangkutan akan menurun. Bila performa jasa lebih tinggi daripada Desired Service maka nasabah akan sangat terkesan dan mungkin juga cukup terkejut pula. Zone of Tolarance adalah jendela dimana nasabah tidak menyadari performa jasa. Bila ia jatuh di luar wilayah yang ada (baik itu sangat rendah maupun sangat tinggi), jasa akan mendapatkan perhatian nasabah baik secara positif maupun negative.

\section{Kualitas Jasa}

Menurut Valarie A.Zeithaml, Mary Jo Bitner \& Dwayne D. Gremler. ${ }^{4}$ Selama bertahun - tahun, para peneliti dibidang jasa telah menemukan bahwa nasabah atau konsumen menilai kualitas sebuah jasa berdasarkan kepada persepsi mereka terhadap aspek hasil teknikal yang disediakan oleh penyedia jasa, proses dimana hasil itu telah diantarkan kepada konsumen, dan juga kualitas daripada lingkungan fisik dimana jasa itu diantarkan kepada konsumen.

Riset juga mengatakan bahwa konsumen tidak menangkap kualitas sebagai suatu aspek yang unidimensional tetapi lebih menilai kualitas dari sudut pandang

\footnotetext{
${ }^{4}$ Valaria A. Zeithaml, Mary Jo Bitner and Dwayne D. Gremler, Service Marketing - Integrating
} Customer Focus Across the Firm, 2006, edition, Mc Graw Hill, New York, hlm. 46 
multideminsial, yang berarti terdapat banyak factor yang relevan terhadap konteks tersebut. Aspek - aspek daripada kualitas jasa telah diidentifikasi melalui riset pionir mengindentifikasi lima aspek spesifik dari kualitas jasa yang relevan terhadap berbagai macam konteks jasa. Sebuah skala juga dikembangkan untuk mengukurnya, SERVQUAL yang terdiri dari lima elemen yaitu : Reliability, Responsiveness, Assurance, Empathy and Tangibles.

a. Reliability didefinisikan sebagai kemampuan untuk melakukan jasa yang dijanjikan secara akurat dan dapat dipercaya.

b. Responsiveness adalah keinginan untuk membantu konsumen dan untuk menyediakan jasa yang baik. Ini berarti menghadapi segala permintaan, pertanyaan, complain dan masalah konsumen.

c. Assurance adalah pengetahuan karyawan dan juga kemampuan perusahaan beserta karyawannya untuk menginspirasikan kepercayaan dan keyakinan kepada konsumennya.

d. Empathy didefinisikan sebagai perhatian yang diindividualisasikan. Yang disediakan oleh perusahaaan kepada konsumennya. Esensinya adalah bahwa konsumen adalah unik dan special dan bahwa kebutuhan mereka dipahami dengan baik.

e. Tangibles didefinisikan sebagai penampilan daripada fasilitas fisik, peralatan, personal, dan materi komunikasi. Aspek ini memberikan respresentasi fisik atau kesan daripada jasa itu diminta konsumennya. Khususnya konsumen atau nasabah baru, yang akan digunakan mengevaluasi kualitas.

Terkait aspek - aspek SERVQUAL, dikembangkan pula sebuah model yang menggambarkan kualitas jasa yang disebut Model Gap Kualitas Jasa ( The Gaps Model of Service Quality). Model ini berupaya untuk menjelaskan hal - hal pokok yang dapat menyebabkan terjadinya perbedaan di dalam kualitas jasa. Menurut Valarie A.Zeithaml, 


\section{Jurnal Asy-Syukriyyah}

Mary Jo Bitner \& Dwayne D. Gremler ${ }^{5}$, model tersebut dapat digambarkan sebagai berikut :

a. The Customer Gap :

Adalah perbedaan antara ekspektasi - ekspektasi konsumen dan persepsi persepsinya. Ekspketasi - ekspektasi konsumen adalah standar atau titik referensi yang dibawa konsumen kedalam pengalaman suatu jasa, sementara persepsi konsumen adalah penilaian subjektif daripada pengalaman jasa sesungguhnya. Ekspektasi - ekspektasi konsumen sering terdiri dari apa yang dipercaya konsumen harus atau akan terjadi.

b. Provider Gap 1 : No Knowing Customer Expect :

Adalah perbedaan antara ekspektasi -ekspektasi konsumen dari suatu jasa dan pemahaman perusahaan terhadap ekspektasi - ekspektasi tersebut. Faktor - faktor kunci yang membawa kepada terjadinya provider gapl adalah sebagai berikut :

1) Orientasi riset pemasaran yang tidak sesuai

2) Kurangnya komunikasi ke atas antara pihak konsumen kepada pihak manajemen

3) Kurangnya fokus hubungan dengan nasabah

4) Tidak sesuainya service recovery

c. Provider Gap 2 : Not Having the Right Service Quality Designs and Standards Adalah perbedaan antara pemahaman perusahaan terhadap ekspektasi - ekspektasi konsumen dan pengembangan desain dan standar daripada jasa yang berfokus kepada konsumen dan pengembangan desain dan standar daripada jasa yang berfokus kepada konsumen. Faktor - faktor kunci yang membawa kepada terjadinya provider gap 2 adalah sebagai berikut :

1) Desain jasa yang buruk

2) Absennya standar yang berfokus kepada konsumen

${ }^{5}$ Valaria A. Zeithaml, Mary Jo Bitner and Dwayne D. Gremler, Service Marketing - Integrating Customer Focus Across the Firm, 2006, edition, Mc Graw Hill, New York, hlm. 46 


\section{Jurnal Asy-Syukriyyah}

3) Bukti fisik dan suasana lingkungan yang tidak sesuai

d. Provider Gap 3 : Not Delivering to Service Designs and Standards

Adalah perbedaan antara pengembangan standar yang berfokus kepada konsumen dan performa sesungguhnya dari jasa itu oleh karyawan perusahaan. Faktor - faktor kunci yang membawa kepada terjadinya provider gap 3 adalah sebagai berikut :

1) Defisiensi didalam kebijakan - kebijakan Sumber Daya Manusia (SDM)

2) Konsumen - konsumen yang tidak memenuhi peranannya

3) Masalah - masalah dengan perantara jasa

4) Kegagalan untuk menyesuaikan antara permintaan dan penawaran

e. Provider Gap 4 : Not Matching Performance to Promise

Adalah perbedaan antara pengiriman suatu jasa dan komunikasi eksternal yang dilakukan oleh pihak penyedia jasa. Faktor - fektor kunci yang membawa kepada terjadinya provider gap 4 adalah sebagai berikut :

1) Kurangnya komunikasi pemasaran jasa yang terpadu

2) Manajemen yang tidak efektif mengenai ekspektasi - ekspektasi nasabah

3) Melebih - lebihkan janji kepada konsumen

4) Komunikasi horizontal yang tidak memadai

\section{Gambar 2}

Model Gap Kualitas Jasa

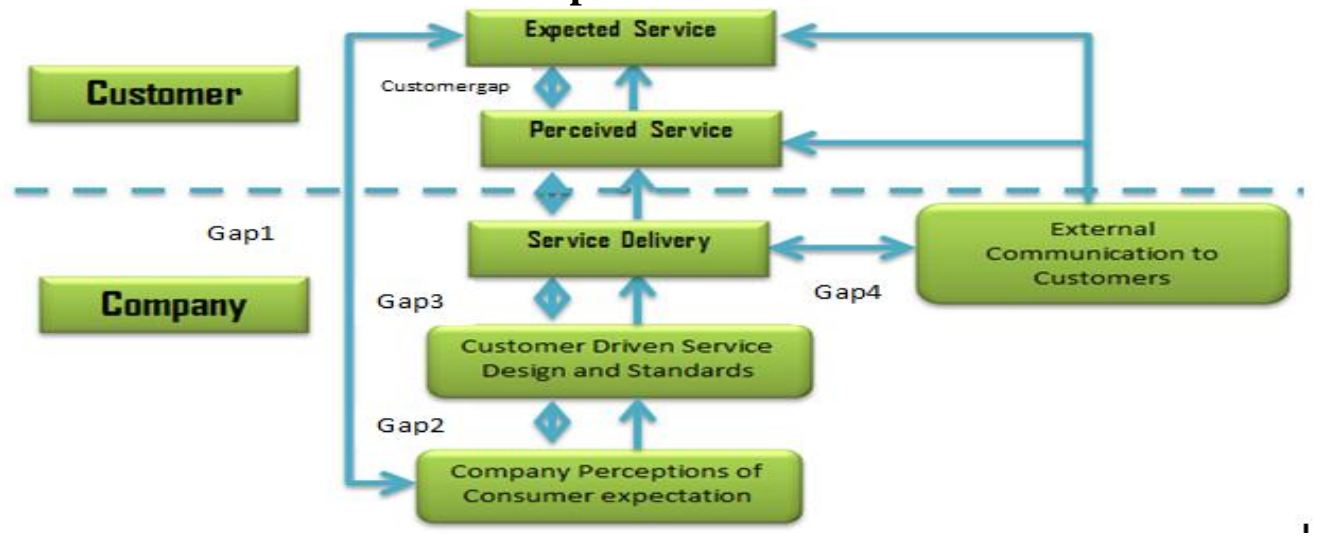

5)

Sumber : Valarie A.Zeithaml, Mery Jo Bitner \& Dwayne D. Gremler, Service' Marketing 


\section{Service Failure}

Definisi Service failure menurut Kim dan Jang : service failure disebut sebagai kegagalan layanan, merupakan segala kesalahan didalam layanan ketika seorang nasabah berhubungan dengan perusahan, yang akan dapatkan mempengaruhi ketidak puasan nasabah $^{6}$

Pakar manajemen jasa, James A. Fitzsimmons \& Mona J. Fitzsimmons, ${ }^{7}$ mengklasifikasikan kegagalan jasa (failed service encounter) ke dalam dua bagian yaitu "Service Error", dan "Customer Error", yang berarti, mereka beranggapan bahwa kegagalan jasa tidak melulu terjadi akibat kelalaian dari pihak penyedia jasa tetapi juga bisa terjadi akibat kelalaian konsumen itu sendiri, seperti yang diuraikan di bawah ini;

a. Server Errors (Penyedia Jasa) :

1) Task :
a. Doing work incorrectly
b. Doing work not required
c. Doing work in the wrong order
d. Doing work too slowly

2) Treatment :
a. Failure to acknowledge the customer
b. Failure to listen to the customer
c. Failure to react appropriately

3) Tangible :
a. Failure to clean facility
b. Failure to provide clean uniforms
c. Failure to control environmental factors

${ }^{6}$ Kim, Jong-Hyeong, and SooCheong (Shwan) Jan 2014, The Fading Affect bias : Examining changes in affect and behavioral intention in restaurant service failure and recoveries. International Journal of Hospitality Management, 40 : hlm. 109 - 119

${ }^{7}$ James A. Fitzsimmons \& Mona J Fitzsimmons, service Management : Operations, Strategy and Information Technology, 2006 


\section{Jurnal Asy-Syukriyyah}

d. Failure to proofread documents

b. Customer errors (Penerima Jasa) :

1) Preparation
a. Failure to bring necessary materials
b. Failure to understand role in transactions
c. Failure to engage the correct service

2) Encounter
a. Failure to remember steps in process
b. Failure to follow system flow
c. Failure to specify desires sufficiently
d. Failure to follow instructions

3) Resolution :
a. Failure to signal service failure
b. Failure to learn from experience
c. Failure to adjust expectations
d. Failure to execute post-encounter action

Fakta membuktikan bahwa layanan service menjadi “zero defect” dalam suatu periode tahun takwin yang biasanya dilakukan oleh dunia perbankan adalah "tidak mungkin dihindari” karena dalam suatu layanan yang diberikan perbankan pasti selalu service failure sangat mengganggu emosional nasabah yang pada akhirnya akan sangat mempengaruhi image perusahaan jika kejadian tersebut terjadi berulang-ulang,

Nathan A Vincent and Cynthia M. Webster, memaparkan dalam jurnal "Emotion and response action in customer complaint behavior", , bahwa pengakuan kognitif terhadap pengalaman tidak memuaskan yang terjadi saat menggunakan suatu jasa menghasilkan munculnya emosi-emosi negative dan juga tendensi untuk

${ }^{8}$ Nathan A Vincent and Cynthia M. Webster, memaparkan dalam jurnal "Emotion and response action in customer complaint behavior, 2005 


\section{Jurnal Asy-Syukriyyah}

melakukan aksi atau tindakan yang sesuai dengan emosi yang dialaminya, ada 7(tujuh) emosi negative sebagai berikut :

1. Emosi eksternal (External emotions)yaitu kemarahan, jijik, menghina, kecewa.

2. Emosi situasional (Situational emotions) yaitu kesedihan ketakutan.

3. Emosi Internal (Internal emotions) yaitu bersalah, malu (Shame), penyesalan

Perlu diperhatikan bahwa klasifikasi emosi sebagaimana telah dilakukan di atas tidak selalu menjadi klasifikasi yang kaku, mengenai emosi-emosi negative yang dialami oleh konsumen yang merasakan ketidakpuasan atas jasa yang mereka terima. Klasifikasi tersebut dapat dipandang sebagai kerangka dasar/basic framework yang dapat dikembangkan lebih luas lagi.

\section{Jenis - Jenis Service Failure :}

1. Kesalahan pelayanan Inti (Core Service Failure), adalah kesalahan layanan yang berkaitan dengan kesalahan yang nyata yang diterima nasabah, contoh dalam kasus perbankan misalnya : rekening nasabah yang terdebit double sehingga berdampak pada ketidakpuasan nasabah tersebut.

2. Kesalahan pelayanan antar personal Interpersonal Service Failure), yakni kesalahan layanan petugas bank dalam berinteraksi dengan nasabahnya, contoh dalam kasus perbankan misalnya : petugas bank menjelaskan informasi yang salah kepada nasabah, terkait nisbah bagi hasil yang berlaku saat ini seharus 67:33 tetapi yang disampaikan petugas bank adalah 65:35.

3. Kesalahan pelayanan dalam procedural (Procedural Service Failure), yakni kesalahan petugas bank dalam menjelaskan tatacara melakukan complain karena ATM yang tertelan

Sedangkan tingkat intensitas kontak hubungan antara petugas bank dengan nasabah bank diklasifikasikan menjadi tiga macam : Rendah, Moderat dan Tinggi 


\section{Jurnal Asy-Syukriyyah}

Tingkat Intensitas Kontak dengan Nasabah menurut Dilworth. ${ }^{9}$

\begin{tabular}{|l|l|l|}
\hline \multicolumn{1}{|c|}{ Kontak Rendah } & \multicolumn{1}{|c|}{ Kontak Moderat } & \multicolumn{1}{c|}{ Kontak Tinggi } \\
\hline Jasa Pos & Restoran & Jasa Konseling \\
Jasa Angkutan & Motel & Rumah Sakit/Dokter \\
Jasa Mail-Order & Pompa Bensin & Transportasi \\
& & Toko Ritel layanan penuh 24 jam \\
\hline
\end{tabular}

Layanan jasa perbankan jika melihat table tersebut di atas, dapat dikategorikan kontak tinggi, karena sesungguhnya layanan perbankan tersebut selama 24 jam penuh, baik melalui opening banking saat jam kerja maupun layanan via online banking. Berdasarkan hal tersebut diatas perbankan perlu melakukan system pelayanan yang baik dengan tingkat akurasi yang tinggi, meningat jumlah nasabah yang tinggi dengan tingkat kebutuhan yang berbeda-beda.

\section{Service Recovery}

Service recovery menurut Kalley dan Davis ${ }^{10}$ dalam Kim dan Jang, merupakan proses sebuah perusahaan untuk memperbaiki sebuah layanan sehingga menjadi lebih baik. Menurut Zeithaml ${ }^{11}$ bahwasanya service recovery adalah layanan jasa yang menunjukkan tindakan yang dilakukan oleh perusahaan ketika mengalami service failure atau kegagalan layanan.

Service recovery merupakan upaya yang sistematis oleh perusahaan setelah terjadinya kegagalan jasa layanan. Hal ini mencakup semua tindakan yang diambil oleh

9 Dilworth, James B, 1992, Operations Management : Design, Planning and Control for Manufacturing and Service. NJ Mc Graw-Hill, Inc

10 Dilworth, James B, 1992, Operations Management : Design, Planning and Control for Manufacturing and Service. NJ Mc Graw-Hill, Inc, hlm. 109-119

${ }^{11}$ Zeithaml, VA. Bitner. M.J. \& Gremler, D.D. 2006, Service Marketing integrating customer focus across the firm $4^{\text {th }}$ ed. Singapore : MC Graw Hill 


\section{Jurnal Asy-Syukriyyah}

penyedia layanan untuk berusaha mengubah dari kegagalan atau kekecewaan menjadi nasabah puas. ${ }^{12}$

Dari beberapa pengertian di atas menurut hemat penulis, service recovery bisa diartikan sebagai tindakan, pemikiran, rencana, dan proses untuk memperbaiki komplen dalam pelayanan nasabah bila terjadi kesalahan atau kekecewaan, dan upaya yang maksimal dari petugas bank dalam mentralisir kembali dari kekecewaan nasabah menjadi minimal normal kembali dan terus me-reenginering layanan secara terus menerus sehingga nasabah menjadi puas.

\section{Service Recovery Strategy}

Service recovery strategy, menurut Blodgett dalam Krishna, ${ }^{13}$ merupakan proses beragam yang berhubungan dengan permintaan maaf, menjelaskan, membuat tawaran kompensasi, dan bersikap sopan dalam proses. Telah ditemukan bahwa setelah kegagalan, menerima tanggung jawab dan penjelasan dalam kombinasi dengan beberapa bentuk kompensasi seperti cash back, kupon atau diskon, telah dilihat oleh nasabah dengan cara yang baik.

Service recovery strategy menggambarkan tindakan penyedia layanan yang dilakukan untuk menanggapi cacat atau kegagalan/kekecewaan, tindakan yang paling umum dan sering digunakan adalah permintaan maaf, bantuan, dan / atau kompensasi. Sedangkan menurut Levesque, Terrence J dan Gordon HG Mc Dougall, ${ }^{14}$ telah membagi recovery strategy untuk tiga kategori : strategi kompensasi moneter, strategi interaksi layanan/asistensi, dan tidak ada strategi tindakan.

${ }^{12}$ Andreassen, T. W, 2000. Antecedents to satisfaction with service recovery, Europen Journal Of Marketing

${ }^{13}$ Andreassen, T. W, 2000. Antecedents to satisfaction with service recovery, Europen Journal Of Marketing hlm. 71-121

${ }^{14}$ Levesque, Terrence J, and Gordon HG Mc Dougall, Service Problems and Recovery Strategies, An Experiment. Canadian Journal of Addministration Sciences 17(1) hlm. : 20-37 


\section{Jurnal Asy-Syukriyyah}

Menurut Anupam Krishna GS Dangayach \& Rakesh Jain ${ }^{15}$ dan yang ditemukan dalam literature terdapat sebagai berikut :

1. Pengakuan : mengakui bahwa masalah telah terjadi

2. Emphati : memahami masalah dari sudut pandang nasabah yang kecewa

3. Meminta maaf : hanya mengatakan maaf

4. Kepemilikan : mengambil kepemilikan nasabah dan masalahnya

5. Perbaikan : memperbaiki atau setidaknya mencoba untuk memperbaiki masalah yang terjadi kepada nasabah

6. Jaminan : memberikan jaminan bahwa masalah/akan disortir dan seharusnya tidak terjadi lagi

7. Kompensasi : memberikan pengembalian dana, atau kompensasi, tergantung tingkat keparahan masalah kegagalan yang dialami

Dari uraian di atas dapat disampaikan bahwa keadilan interaksional dari suatu kegagalan layanan adalah merupakan bagian yang sangat penting bagi pemulihan kegagalan layanan yang melibatkan cara dimana orang yang diperlakukan selama proses penanganan keluhan termasuk unsur-unsur kesopanan diperlihatkan penyedia jasa dalam menanganinya, seperti halnya : empathi, dan kesungguhan perbankan dalam menangani keluhan yang terjadi dalam upaya mencari solusi yang efektif dan efisien, sehingga upaya menenangkan nasabah dalam penyelesaian permasalahannya dapat dilakukan dengan baik

\section{Customer Anger}

Anger :

Menurut Shahsavarani, ${ }^{16}$ Anger merupakan kemarahan sebagai emosi yang negative, sebagai keadaan gairah, yang mengalami sebagai bertentangan dengan seseorang atau hal yang tampaknya menjadi sumber dari adanya permusuhan.

${ }^{15}$ Andreassen, T. W, 2000. Antecedents to satisfaction with service recovery, Europen Journal Of Marketing hlm. 71-121 


\section{Jurnal Asy-Syukriyyah}

Amaarah menurut Palaparthu dan Reni ${ }^{17}$ didefinisikan sebagai reaksi emosional akut, yang dicetuskan dengan beberapa keadaan seperti adanya ancaman, agresi, tertekan, serangan verbal, kekecewaan atau kegagalan. Amarah merupakan keadaan emosi yang paling primitive, dialami seluruh tingkat usia, dan timbul secara teratur dalam kehidupan setiap orang dan merupakan keadaan emosi yang umum terjadi dalam keadaan interpersonal yang stressful. Menjadi marah diperkirakan aksi agresif dan merasa marah diperkirakan merupakan kesadaran subjektif terhadap adanya impuls agresif.

Emosi dapat didefinisikan sebagai proses dengan jangka waktu tertentu yang bersumber dari pngalaman pribadi dan kemampuan individu sehubungan dengan masalah - masalah yang dianggap penting sehingga individu memiliki kemampuan untuk mempersiapkan diri untuk bertindak, bereaksi dan memiliki perencanaan ${ }^{18}$. Kemarahan adalah salah satu emosi utama yang sering dialami oleh kebanyakan orang dalam kehidupan sehari - hari . bertentangan dengan pendapat pada umumnya, kemarahan tidak semata - mata

Sebagai bentuk penerapan dimensi - dimensi psikologis untuk layanan konteks service failure dan service recovery strategy, kegagalan layanan dapat menyebabkan kemarahan dan dapat dibagi menjadi dua kategori berdasarkan penyebabnya yaitu : (1) eksternal dan (2) non-eksternal. Dari perspektif nasabah, sevice failure eksternal disebabkan oleh penyedia layanan. Sebaliknya, kegagalan layanan non eksternal yang disebabkan oleh nasabah, oleh situasi, atau karena nasabah tidak tahu siapa atau apa yang menyebabkan masalah tersebut. Misalnya, jika seorang nasabah harus

${ }^{16}$ Shahsavarani,M,A., Noohi, S., Jafari, Maryam Hakimi, Samira Hatefi, 2015 Assesment \& Measurement of Anger in Behavior and Sosial Sciences : A Systematic Review of Literature. International Journal Of Medical Review 2(3) hlm. 279 - 286

${ }^{17}$ Palaparthi, N and Rani, K. J., 2012 A Study of Anger Expression as a Dimension of Workplace Emotion. International Journal of Multidiciplinary Research, $2 \mathrm{hlm} .5$

${ }^{18}$ Shahsavarani,M,A., Noohi, S., Jafari, Maryam Hakimi, Samira Hatefi, 2015 Assesment \& Measurement of Anger in Behavior and Sosial Sciences : A Systematic Review of Literature. International Journal Of Medical Review 2(3) hlm. 279 - 286 


\section{Jurnal Asy-Syukriyyah}

menunggu selama 1(satu) jam di counter Customer Service, meskipun dia telah membuat janji dan tiba tepat waktu, ini akan dinilai sebagai kegagalan. Nasabah mungkin berpikir bahwa menunggu lama disebabkan oleh Customer Service yang tidak dapat mengatur jadwal dengan akurat. Masalah ini disebut sebagai kegagalan servie eksternal, hal ini menjadi kesalahan petugas Customer Service. ${ }^{19}$

\section{Pengukuran Customer Anger :}

Pengukuran kemarahan nasabah (Customer Anger) dalam penelitian ini menghadapi skala yang dikembangkan $N_{\text {ovaco }}{ }^{20}$, yang meliputi : anger justification, Rumination, Somatic Tension, Impulsive reaction, verbal aggression, Anger justification merupakan pembenaran seseorang terhadap perasaan marah yang dirasakan, sedangkan Rumminations diartikan sebagai Merenungkan atas pelayanan yang dapat menyebabkan perasaan marah. Somatic Tension adalah keterangan fisik yang dialami selama terjadinya perasaan marah yang dirasakan, sedangkan Rumination diartikan sebagai merenungkan atas pelayanan yang dapat menyebabkan perasaan marah. Somatic Tension adalah keterangan fisik yang dialami selama terjadinya perasaan marah, untuk Impulsive reaction adalah reaksi spontan terhadap situasi yang membuat marah, dan verbal agression adalah agresivitas verbal sebagai reaksi terhadap perasaan marah yang dialami.

Penulis mencoba melakukan analisis dengan pendekatan kualitatif untuk sebab terjadinya Service failure yang disebabkan atas beberapa dimensi - dimensi diantaranya adalah : Prosedur perbankan, kesalahankesalahan, perilaku dan training karyawan, kesalahan-kesalahan fungsional/teknikal, segala sesuatu yang dilakukan maupun tidak dilakukan oleh bank yang bertentangan dengan etika perdagangan yang fair secara signifikan berpengaruh negatif terhadap behavioral intentions. Hal ini berarti bahwa dalam

${ }^{19}$ Nguyen, Doan T. \& Janet R. MC. Coll-Kennedy, 2003. Diffusing Customer Anger in service Recovery: A Conceptual Framework. Australian Marketing Journal. hlm. 2

${ }^{20}$ Novaco, R.W, 2000, Anger In A E Kazdin (Ed), Encyclopedia of Psychology, Washington, DC : American Psychological Association and Oxford University Press 


\section{Jurnal Asy-Syukriyyah}

layanan perbankan terdapat kemungkinan terjadi kegagalan layanan sehubungan berbagai aspek layanan.

Dampak kegagalan ini berpengaruh negatif terhadap behavioral intentions. Artinya, jika nasabah mengalami ketidakpuasan dalam layanan akan menurunkan niat membeli produk jasa perbankan, keperilakuan yang ditunjukkan oleh perilaku negatif dalam komunikasi dari mulut ke mulut, niat menggunakan jasa bank dan perilaku komplain. Jika ini terjadi maka akan berakibat buruk bagi pihak bank. Maka, jika terjadi service failure bank harus melakukan strategi recovery yang tepat sehingga kondisi suasan nasabah yang kecewa dapat normal kembali.

Upaya - upaya yang dilakukan oleh perbankan syariah biasanya dalam menetralisir kegagalan layanan dilakukan dengan cara pemulihan layanan (Service recovery) dengan pendekatan 7 indikator (koreksi, perlakuan khusus, penjelasan, permohonan maaf, menyampaikan keluhan pelanggan kepada atasan, pemberian kompensasi, dan tidak melakukan apapun) berpengaruh positif terhadap behavioral intentions. Hal ini berarti bahwa tujuh tindakan recovery tersebut merupakan penentu terjadinya behavioral intentions yang berupa komunikasi dari mulut ke mulut (word-ofmouth (WOM) communications), niat membeli produk jasa perbankan syariah (purchase intentions), perilaku komplain (complaining behavior). Hal ini menunjukkan bahwa jika bank melakukan recovery yang tepat untuk kegagalan layanan yang terjadi, nasabah akan menunjukkan behavioral intentions yang baik. Tindakan recovery yang memuaskan akan memunculkan niat keperilakuan yang positif dari nasabah, yang ditunjukkan oleh perilaku positif dalam komunikasi dari mulut ke mulut, niat beli dan perilaku komplain.

Secara bersama-sama, service failure dan service recovery berpengaruh signifikan positif terhadap behavioral intentions. Service failure yang tidak mungkin dihindari seluruhnya oleh bank, jika diikuti oleh recovery yang efektif akan menyebabkan munculnya niat keperilakuan yang positif dari nasabah, yang ditunjukkan oleh perilaku positif dalam komunikasi dari mulut ke mulut, niat beli dan perilaku komplain. 


\section{Jurnal Asy-Syukriyyah}

Upaya pencegahan kegagalan layanan dilakukan dengan cara, bank perlu menyusun strategi untuk mencegah terjadinya service failure sekaligus mempersiapkan strategi yang tepat untuk recovery terhadap setiap failure yang terjadi, supaya tercipta behavioral intentions. Biasanya perbankan membentuk unit khusus yang menangani khusus penanganan problematka Nasabah seperti Di Danamon melalui : Danamon Akes Center (DAC)

Perbankan Syariah sebagai industri jasa perbankan hendaklah dapat melibatkan interaksi personal tingkat tinggi antara staf bank dan pelanggan, sehingga adanya miskomunikasi akan mengakibatkan terjadinya service failure. Kualitas layanan sering ditunjukkan oleh perilaku staf front-line, dengan pengalaman dan komitmen yang terbatas serta sikap yang bervariasi antara satu layanan dengan layanan lainnya. Tidak terpisahnya antara produksi dan konsumsi berarti bahwa kegagalan yang terjadi adalah pada saat konsumsi, sehingga hanya ada sedikit kesempatan untuk memperbaiki kesalahan tersebut tanpa membuat pelanggan merasa tidak nyaman.

\section{KESIMPULAN}

Kesimpulan Penulis bermaksud untuk menganalisis pengaruh service failure dan service recovery terhadap behavioral intentions dalam layanan perbankan. Hasil analisis dengan pendekatan kualitatif berdasarkan analisis teori para ahli menunjukkan service failure merupakan kesalahan-kesalahan yang terjadi dalam layanan, yang berupa tidak tersedianya layanan, layanan yang terlalu lambat dan kesalahan-kesalahan lainnya. Kesalahan atau kegagalan dalam layanan ini akan berpengaruh negatif terhadap behavioral intentions.

Selanjutnya upaya yang dilakukan dalam mengatasi kegagalan layanan dilakukan dengan strategi service recovery ternyata upaya yang dilakukan berdampak terhadap behavioral intentions. Sehingga proses service recovery yang dilakukan perbankan dalam penanganan yang tepat atas kegagalan layanan yang terjadi berpengaruh positif terhadap behavioral intentions. Kedua variabel independen berpengaruh signifikan terhadap 


\section{Jurnal Asy-Syukriyyah}

variabel dependen. Ini berarti bahwa terjadinya service failure yang disertai dengan strategi service recovery yang positif akan menyebabkan terjadinya behavioral intentions.

Dengan kata lain, jika pelanggan mengalami ketidakpuasan kemudian pihak bank memperbaiki ketidakpuasan tersebut, maka pelanggan akan berniat untuk tetap bertahan sebagai nasabah yang menggunakan jasa bank itu. 


\section{Jurnal Asy-Syukriyyah}

\section{DAFTAR PUSTAKA}

Andreassen, T. W, 2000. Antecedents to satisfaction with service recovery, Europen Journal Of Marketing

Dilworth, James B, 1992, Operations Management : Design, Planning and Control for Manufacturing and Service. NJ Mc Graw-Hill, Inc

James A. Fitzsimmons \& Mona J Fitzsimmons, service Management : Operations, Strategy and Information Technology, 2006 Integrating Customer Focus Across the Firm, 2006, Mc Graw Hill, New Yor.

Krishna, Anupam,GS Dangayach \& Rakesh Jain, 2011, Service Recovery Literatur Review and Research Issue. Journal of Service Science Research.

Levesque, Terrence J, and Gordon HG Mc Dougall, Service Problems and Recovery Strategies, An Experiment. Canadian Journal of Addministration Sciences

Lewis, B.R., \& Spyrakopoulos, S. 2001, Service Failures and Recovery in Retail Banking: the Customers' Perspective, Vol.19, No.1,

Matilla. 2001. The Effectiveness of Service Recovery in Multi-industry Setting. The Journal of Service Marketing. Vol.15, No.4,

McCole, 2004 Dealing with complaints in service. International Journal of Contemporary Hospitality Management. Vol. 16 No. 6, 345-354

McCollough, M.A., Berry, LL., Yadav, M.S. 2000. An Empirical Investigation of Customer Satisfaction After Service Failure And Recovery. Journal of Service Research, Vol.3,

Nathan A Vincent and Cynthia M. Webster, memaparkan dalam jurnal "Emotion and response action in customer complaint behavior, 2005

Nguyen, Doan T. \& Janet R. MC. Coll-Kennedy, 2003. Diffusing Customer Anger in service Recovery: A Conceptual Framework. Australian Marketing Journal.

Novaco, R.W, 2000, Anger In A E Kazdin (Ed), Encyclopedia of Psychology, Washington, DC : American Psychological Association and Oxford University Press

Otoritas Jasa Keuangan (OJK), laporan rutin bulanan perbankan 


\section{Jurnal Asy-Syukriyyah}

Palaparthi, N and Rani, K. J., 2012 A Study of Anger Expression as a Dimension of Workplace Emotion. International Journal of Multidiciplinary Research,

Shahsavarani,M,A., Noohi, S., Jafari, Maryam Hakimi, Samira Hatefi, 2015 Assesment \& Measurement of Anger in Behavior and Sosial Sciences : A Systematic Review of Literature. International Journal Of Medical Review

Valaria A. Zeithaml, Mary Jo Bitner and Dwayne D. Gremler, Service Marketing - I Kim, Jong-Hyeong, and SooCheong (Shwan) Jan 2014, The Fading Affect bias : Examining changes in affect and behavioral intention in restaurant service failure and recoveries. International Journal of Hospitality Management, 40 : 